\title{
Rune Grubb
}

1920-1998

Torgny Hallberg

Department of Medical Microbiology, Lund University, Lund, Sweden

Professor Rune Grubb died on August 20, 1998, in Lund, Sweden.

He was born on May 22, 1920, in Växjö, Sweden, the son of Rut and Eric Grubb, both physicians. He grew up in Växjö in the woodland of county Småland, an area he returned to all his life for reflection and recreation.

He got his medical education at Lund University and partly also at the Karolinska Institute, Stockholm, and received his licence as a physician in Lund in 1946. As a young student Rune Grubb started scientific work at the Institute of Bacteriology, Lund University. Immediately after the war, in 1945, he moved to the State Serum Institute, Copenhagen as a guest scientist, and for a more extended period to the Lister Institute, London, where he collaborated among others with W.T.J. Morgan and A.E. Mourant. During the Lister Institute period he produced a number of now classical papers in blood group genetics [1-4], delineating the systematics of the Lewis blood groups and their relation to $\mathrm{ABO}$ and secretor groups. This work has been fundamental to our understanding of these important blood group systems. Back in Sweden he presented his $\mathrm{PhD}$ thesis, 'Some Aspects of the Complexity of the Human ABO Blood

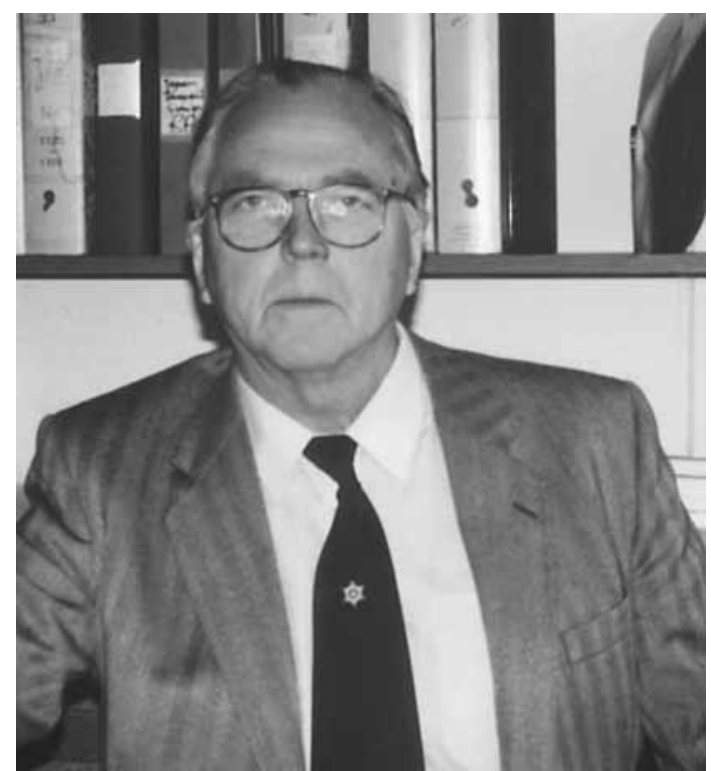

Groups', in Lund in 1949. This area, immunogenetics and genetic markers of the individual, remained in the center of his scientific interest for the rest of his life. Following graduation he took up a position as Assistant Professor and later as Associate Professor of Bacteriology at Lund University (1949-1959).

\begin{tabular}{ll}
\hline KARGER & (1) 1999 S. Karger AG, Basel \\
0254-9670/99/0161-0061\$17.50/0 \\
$\begin{array}{l}\text { Fax +4161306 1234 } \\
\begin{array}{l}\text { E-Mail karger@karger.ch } \\
\text { www.karger.com }\end{array}\end{array}$ & $\begin{array}{l}\text { Accessible online at: } \\
\text { http://BioMedNet.com/karger }\end{array}$
\end{tabular}


In 1955, studying infection-prone hypogammaglobulinaemic patients, Rune Grubb used the Coombs consumption haemagglutination-inhibition test to demonstrate minute amounts of human gamma globulin. Along with it, it was found that one serum agglutinated the anti-Rh-coated erythrocytes used as indicator cells in the test. Further studies demonstrated that this serum contained an anti-immunoglobulin (Ig) and similar anti-Ig were found in sera from many patients with rheumatoid arthritis. Only certain combinations of anti-Ig and anti-Rh worked together. Further observations including inhibition tests and family studies established the existence of a genetic marker of human Ig with a strict mendelian mode of inheritance. This discovery of the allotypic variation of human IgG was published from 1956 onwards again in a series of now classical papers [5-10]. The allotypes were denoted ' $\mathrm{Gm}$ groups', originally standing for ' $g a m m a$ globulin' but later elegantly converted to denote 'genetic markers' of human $\mathrm{IgG}$.

The importance and impact of the discovery of a strictly mendelian system of genetic markers for human Ig might not be self-evident in today's era of molecular biology. However, it definitely proved that antibody synthesis is under genetic control, a view far from self-evident in those days when the instructive theory of antibody synthesis still had a number of strong and eloquent proponents.

In 1959 Rune Grubb was appointed Professor of Bacteriology and Head of the Department of Medical Microbiology, Lund University, a position he held up to 1986 . As a retired professor he still kept a study and working bench at the department.

During the 1960s the majority of human Ig genetic markers that we know of today were described by various laboratories and Rune Grubb critically compiled data of the human Ig allotypes [11-13]. Further work in Rune
Grubb's laboratory on the structure and genetics of human IgG led to additional fundamental discoveries. Use of myeloma proteins and combinations of protein chemistry and genetic analysis demonstrated the strict correlation of Gm markers and particular IgG subclasses. Studies, in which his pupil Lars Mårtensson played a decisive role, demonstrated the phenomenon of 'allelic exclusion', then unknown in man [14-16]. One problem continued to occupy Rune Grubb since the discovery of the first Gm allotype and the antiallotypes in sera from rheumatoid arthritis patients. How is it possible that certain individuals produce antibodies against Ig determinants to which they have never been exposed? This question had been elaborated upon from time to time in a series of papers but became the very focus of his scientific interest during the last period of his life.

In the search for explanations the phenomenon of so-called 'non-nominal allotypes' became an essential piece of the puzzle. Observations consistent with the presence of nonnominal allotypes have been published since the 1970s and a definite explanation for their origin is still lacking. Rune Grubb proposed that a 'gene transfer mechanism' could explain both the non-nominal allotypes and production of anti-allotypic antibodies [17]. The theory implies that Ig gene segments are transferred by virus and incorporated in an episome-like manner in the genome of Ig-producing cells. The gene product includes nonnominal allotypes, that is Ig markers to which the individual lacks tolerance. These allotypes form the antigenic stimulus for the production of anti-allotypic antibodies, including rheumatoid factors. The concept of 'gene transfer disease' was born.

In spite of a progressing disease Rune Grubb elaborated upon the theory, also seeking experimental evidence in collaboration with coworkers in virology and molecular ge- 
netics. He epitomized the theory in a paper [18] entitled 'Rheumatoid Arthritis - A Gene Transfer Disease' sent to this journal and appearing in the present issue. The letter of acceptance reached him the week before he died.

The last months of his life Rune Grubb was intensely engaged in preparing for a scientific symposium, Gene Transfer Disease, to be held in Lund, Sweden, on September 3-4, 1998. Unfortunately he died a short time before this symposium. The inaugural speech was intended to be given by Rune Grubb. Instead his son and coworker Anders held it from his father's manuscript. The symposium was moving and scientifically fruitful for all participants.

It is natural that Rune Grubb's skill and good judgement was in demand for a number of missions during his tenure as Professor and Head of the Department of Medical Microbiology and the Laboratory of Clinical Bacteriology. He mastered the design of the site of the new institute including both the clinical laboratory and the university department. The institute moved in 1967 from the wellknown address 'Paradise Street' (Paradisga$\tan 5$ ) to the new modern site where the different branches of medical microbiology were fruitfully interwoven in a local and intellectual community. Rune Grubb took a keen part in the clinical and educational work. He had a broad and deep knowledge of both bacteriology and immunology and as head physician of the laboratory he took an active part in the diagnostic work, especially the mycobacterial analyses. A significant number of $\mathrm{PhD}$ theses were done at the institute during these years and many of his pupils later took up leading positions at university departments and clinical laboratories in various parts of Sweden.

He held a number of official positions including Executive Head Physician at Lund
University Hospital 1982-1983, Member of the Swedish Medical Research Council, and Advisor to the Swedish National Board of Health and Welfare. He was a Honorary Member of the American Society for Immunology since 1965 and a member of the Swedish Royal Academy of Sciences since 1971 and had been invited to hold honorary lectures at scientific meetings in various parts of the world.

Rune Grubb's personality was marked by a high degree of humanism and a deep feeling for nature. Using immunogenetics as a weapon he assailed narrow-mindedness and xenophobia, and in sensitive essays he shared with us his experiences from the lakes and woodlands of his native county of Småland. We remember Rune Grubb as a great complex personality in whom the clear reasoning and the unconditioned integrity formed the very core. The scientific community has lost a great scientist and pathfinder. His friends and collaborators feel the deep loss of a reliable and truthful friend. 


\section{Selected References from Rune Grubb's Bibliography}

1 Grubb R: Correlation between Lewis blood group and secretor character in man. Nature 1948;162:933.

2 Grubb R, Andresen PH, Callender ST, Fisher RA, Morgan WTJ, Mourant $\mathrm{AE}$, Pickles MM, Race RR: A notation for the Lewis and Lutheran blood-group systems. Nature 1949; 163:580-581.

3 Grubb R, Morgan WTJ: The 'Lewis' blood group characters of erythrocytes and body fluids. Br J Exp Pathol 1949;30:198-208.

4 Grubb R: Observations on the human group system Lewis. Acta Pathol Microbiol Scand 1951;28:6181.

5 Grubb R: Agglutination of erythrocytes coated with 'incomplete' anti$\mathrm{Rh}$ by certain rheumatoid arthritic sera and some other sera. The existence of human serum groups. Acta Pathol Microbiol Scand 1956;39: 195-197.

6 Grubb R, Laurell A-B: Hereditary serological human serum groups. Acta Pathol Microbiol Scand 1956; 39:390-398.
7 Grubb R: Reaction of rheumatoid arthritic sera with a human antibody gamma globulin. Acta Rheumato Scand 1957;3:55-58

8 Grubb R: A relationship between blood group serology and rheumatoid arthritis serology. Serum protein groups. Vox Sang 1957;2:305312.

9 Grubb R: Hereditary gamma globulin groups in man. Ciba Foundation Symposium on Biochemistry of $\mathrm{Hu}-$ man Genetics. Churchill, London, 1959, pp 264-273.

10 Grubb R: The discovery of the genetic markers of human immunoglobulins. Vox Sang 1983;45:89-90.

11 Grubb R: The Genetic Markers of Human Immunoglobulins. Berlin, Springer, 1970.

12 Grubb R: Immunogenetic markers as probes for polymorphism, gene regulation and gene transfer in man - The Gm system in perspective. Acta Pathol Microbiol Scand 1991; 99:199-209.

13 Grubb R: Human immunoglobulin allotypes and mendelian polymorphisms of the human immunoglobulin genes; in van Ross CJ, van Regenmortel MHV (eds): Immunochemistry. New York, Dekker, 1994, pp 47-68.
14 Kunkel HG, Allen JC, Grey HM, Mårtensson L, Grubb R: A relationship between the $\mathrm{H}$ chain groups of 7S $\gamma$-globulin and the $\mathrm{Gm}$ system. Nature 1964;203:413-414.

15 Grubb R, Kronvall G, Mårtensson $\mathrm{L}$ : Some aspects of the relations between rheumatoid arthritis, antigamma-globulin factors and the polymorphism of human gamma globulin. Ann NY Acad Sci 1965; 124:865-872.

16 Grubb R: Mendelian Inheritance of Ig Polymorphism. Allelic Exclusion in Man. Protides of the Biological Fluids. Proc 17th Colloq, Bruges 1969. Oxford, Pergamon Press, 1970, pp 107-110.

17 Grubb R, Kjellén L: On the origin of antibodies to immunoglobulin genetic markers in rheumatoid arthritis. An outline of a novel concept of the nature of rheumatoid arthritis Transduction in man. Exp Clin Immunogenet 1989;6:88-98.

18 Grubb R, Grubb A, Kjellén L, Lycke E, Åman P: Rheumatoid arthritis A gene transfer disease. Exp Clin Immunogenet 1999;16:1-7. 